\title{
10 Christian religious understandings and responses to COVID-19 in Eswatini
}

\author{
Sonene Nyawo
}

\section{Introduction}

The population of Eswatini (formerly Swaziland) estimated at 1.2 million is struggling to cope with the escalating numbers of confirmed cases of COVID-19 pandemic. This unprecedented health phenomenon has affected all sectors of human and business life. It has also received a lot of attention and interpretations regarding its origins, intentions and eventually, how it is going to recede. In most cases, these have either been economic, biological and or mystical/spiritual. As measures of trying to 'flatten the curve' as many would call it, local and international authorities have come up with strategies and regulations that guide human activities across the globe. The main mandate of such has been to reduce human to human transmission of the virus. This has seen many nations embarking on lockdowns, which have restricted the operation of multiple sectors of business that were deemed as not being essential. Restrictions in people's movement both locally and internationally, and assembling in mass gatherings, amongst a range of other preventative measures, were also introduced. The U.N. Secretary-General, Antonio Guterres, in April 2020 when he was appealing to religious leaders of all faiths to unite in fighting against COVID-19 stated that "[t]he coronavirus pandemic, with its lockdowns and social distancing, has led to a "surreal world" of silent streets, shuttered stores, empty places of worship and of worry" (Guterres 2020). This shows that the pandemic had far reaching effects to different communities, nations and states. Eswatini's first case of COVID-19 was confirmed on 14 March 2020, and infections and deaths have continued to rise drastically.

In terms on religion, legislatively, Eswatini has no official religion, but everyday practices point to Christianity's overriding popularity. Whilst the country's constitution prohibits religious discrimination and provides for freedom of thought, conscience, and religion, including the right to worship, alone or in community with others, and to change religion or belief, most Emaswati identify as Christian (International Religious Freedom Report: Swaziland 2019 International Religious Freedom Report: Eswatini. 2019. Washington: Bureau of Democracy, Human Rights, and Labor, U.S. 
Department of State [Google Scholar]). Forms of Swazi Traditional Religion like divination, herbal healing and environmental and ancestral spirit veneration also make up this religious landscape and elide with Swazi culture, a reified set of practices and values shored up by the monarchy in national ceremonies, clothing, tourism, heritage programming and everyday ideations of custom (Golomski \& Nyawo 2017). Christian churches affiliate to three ecumenical bodies: the Eswatini Conference of Churches (ECC formerly SCC), the Council of Swaziland Churches ${ }^{1}$ (CSC) and the League of African Churches in Eswatini (LACE formerly LACS).

Churches previously established by European and US missionaries founded the SCC in 1929. The overriding aim of SCC had been to foster cooperation among the various mission churches engaged in Christian evangelism and includes several Protestant churches like Church of the Nazarene, Assemblies of God and the Evangelical Church. The SCC experienced a schism in 1976 when liberal members withdrew to form the CSC, which includes the Catholic, Methodist and Anglican churches. While SCC has primary aims in building new churches and conversion, CSC strives to address social concerns in society such as poverty, underdevelopment and injustice. Unlike SCC and CSC, King Sobhuza II formed LACS in the early-1940s in liaison with clergy belonging to African Independent Churches and in response to attempts by the British colonial government and some European missionaries to ban these churches in the then Swaziland. Given Sobhuza's legitimation and mentorship role in the formation of this body, the constitution of LACS recognises the King as its life-long patron, and LACS has been credited with rendering unequivocal support for Swati cultural nationalism (Golomski \& Nyawo 2017). Like CSC and ECC, LACE aims to promote fellowship and unity among churches. Aside from a few limited instances (International Religious Freedom Report: Eswatini 2019 International Religious Freedom Report: Eswatini. 2019. Washington: Bureau of Democracy, Human Rights, and Labor, U.S. Department of State [Google Scholar]), there is an overall climate of religious tolerance in Eswatini and between different Christian churches.

People in this predominantly Christian and traditional nation interpret and understand their circumstances in accordance with their religious thought patterns; thus, many fascinating behaviours are performed in the name of religion (Hood et al. 2001). During difficult moments in life, they seek and collaborate with God, in solving both minor and major stressors (del Castillo \& Alino 2020); hence Koenig's (2012) submission that numerous empirical studies identify religion as an integral part of human existence. With regard to COVID-19 pandemic, like elsewhere in the world, its dire effects have destabilised Emaswati; it has strained the social fabric, threatened the health care operations, and has put the faith of many Christians to test (del Castillo et al. 2020). However, religious beliefs which are powerful and coherent forces, as described by Barmania \& Reiss (2020), become a coping resource (Hart \& Koenig 2020). The chapter therefore seeks to establish that 
whilst Christians in Eswatini hold various religious understandings of the pandemic, which can be a coping resource, the reality is that the pandemic continues to represent a significant stressor for the nation; fear of death and suffering is acutely elevated, Emaswati are ill, hungry and bereaved. The solution lies with church leaders as 'gatekeepers', that they should change their mindset towards COVID-19 and face reality that it is wrecking lives. Thus, they would need to balance religion with practical steps to reduce infections.

\section{How Christians understand COVID-19 ${ }^{2}$}

In as much as the drivers of the world economies alongside health practitioners have had a lot to say in response to COVID-19, the Christian community that experience Christ within their traditional thought patterns have also contributed to our understanding of the current situation in Eswatini. Christians have seen it as a punishment for sin; a spiritual warfare; and a fulfilment of biblical prophecies about the end times. The enquiry that then arises is that can Christian responses to the pandemic bind the nation together and contribute to successfully coping with the pandemic, or might they lead to low perception of risk and create a fatalistic attitude in the face of the virus?

\section{COVID-19 is God's punishment for sin}

In the Church's response to the COVID-19 pandemic, the most recurring theme has been that the nation has sinned against God, and Emaswati have to fast and pray for God's forgiveness. There have been national prayers convened by the Ministry of Home Affairs, at the King's directive, to carry out this mandate. His Majesty King Mswati III through the Prime Minister of Eswatini Ambrose Mandvulo Dlamini declared a national day of fasting on March 28, 2020, which was followed by the National Day of Prayer the next day. The theme of the prayer was 'God heal our land', whilst the theme verse was 2 Chronicles 2:13-14 which called the nation to repent from wickedness. The prayer was attended by 20 people; pastors and leaders of the three Christian ecumenical bodies; some cabinet ministers; and royalty. The rest of the nation was invited to follow proceedings of service through live broadcast in various media platforms, whilst "they convert their homes into altars, ask for God's forgiveness and seek God's intervention so that no one would die from the virus" (Eswatini News March 28, 2020). As every Liswati was urged to observe the fast, "those on medication were advised to take the 'Daniel's fast', which would allow them to eat vegetables", said the Minister of Home Affairs (Eswatini News March 28, 2020).

As they were motivating the theme of the national prayer, sermons and prayers by selected church pastors from the three ecumenical bodies made it clear that the nation had sinned against God, hence COVID-19, but 
now it was repenting and pleading for God's forgiveness. They likened the COVID-19 situation in Eswatini to that of the nation of Israel in the wilderness. The Israelites sinned against God, and He sent snakes to punish them for speaking against him and Moses (Numbers 21:4-9). The people came to Moses to repent and asked him to pray to God to remove the serpents. The bronze serpent on a pole which God told Moses to erect so that the Israelites who saw it would be protected from dying from the bites of the "fiery serpents" was therefore God's response to their repentance. The sermons during the prayer also gave hope to the nation that life and economy shall be restored after the outbreak. One cleric was reported to have claimed that

no liSwati would die from COVID-19 if the nation would repent and put their trust in God....and the world would ask how we managed to survive the virus and we will tell them that it is because Jesus is our shield as a nation.

(Times of Eswatini, 30 May 2020)

Still pursuing the same theme in another forum, one pastor claimed to have received a prophecy from God that brings hope to Emaswati that "they would come out of the coronavirus pandemic without scratches" (Times of Eswatini April 14 2020). During this period some Christians would also embark in corporate prayers at the mountains, where they would plead for God's mercy over the nation of Eswatini.

\section{COVID-19 is a spiritual warfare}

There is another perspective advanced by many Christians that the emergence of the pandemic is a spiritual warfare between God and Satan, and that it calls for spiritual strategies to combat its effects and save human life. A publication by a church leader in local print media had this comment about the health crises;

to understand the Corona pandemic, we have to take into account that there are two Kingdoms presently at war in the earth; the Kingdom of God (Light) and the Kingdom of Satan (Darkness). This war has been playing itself for many centuries and what people have been seeing at times as natural phenomenon has actually been the manifestation of the war between these two Kingdoms. As we draw closer to the end times, the war between these Kingdoms will become even more and more visible. Unfortunately, every war has casualties and this one is no exception.

(Dlamini 2020)

He further suggested that the current phenomenon therefore must be understood from a biblical perspective as the battle between the two Kingdoms 
which becomes fiercer. At the root of this battle is worship, and Satan's ultimate plan is to get the entire world to worship him (Revelations 13:11).

There are other Christians who share similar sentiments about COVID-19 that it is a spiritual warfare. More arguments in print media emphasise claims that the universe has two kingdoms, the Kingdom of Light which is of God, and that of the darkness belonging to the Satan. At the top of the Kingdom of darkness, there is the devil and he has structured his kingdom (Ephesians 6:12) to mimic that of the Kingdom of God. The devil operates through that structure and unfortunately through people. God also operates through His structure of the believers. There are things in the Old Testament that are a shade of the New Testament while theologians suggest that the New Testament is the Old Testament revealed; hence Christians can learn a lot from the events of the Old Testament to explain events happening in the present times. God used plagues in the Old Testament to pass judgment on the gods of Egypt during or before the Exodus and that God can also use plagues like COVID-19 as judgement on Satan and his demons.

One church was cited in local print media to have said;

other interesting factors that might also help in understanding the Coronavirus is that we know that when the devil planned to murder Jesus, he thought he was winning the battle but that led to his defeat (1 Corinthians 2:8). God allowed him to believe he is on top only to realize later that he was orchestrating his own demise.

(Dlamini 2020)

According to this argument when the devil had Jesus killed, he must have had a short-lived celebration until he realized the full picture that the title deeds of the earth no longer belonged to him. In the same manner, when the devil used Joseph's brothers to sell him into captivity, he thought he was frustrating God's plan about Joseph yet in actual fact, he was facilitating it. That is why Romans 8:28 says 'and we know that God causes everything to work together for the good of those who love God and are called according to his purpose for them.' "So, if we suppose the Coronavirus is the plan of the devil, then we know that God is one step ahead of him. If the Corona was released by evil people, then they would have been employed by the devil. If the devil is not part of it, then it is purely an act of God", adds the church leader (Dlamini 2020).

\section{COVID-19 is fulfilment of end time prophecies}

Whilst to some Emaswati COVID-19 is a punishment from God, and also a spiritual warfare, to others it is a sign of the second coming of Jesus Christ. Christians have mostly been referring to the scriptures that list the signs of the end times in which the prophecies state that there will be wars, nation against nation, natural disasters and pestilences (Matthew 24 7-8; Luke 21 
11). With this being shown from the evidence of the scriptures, they perceive the outbreak of the coronavirus as one of the specific signs of Jesus' coming and of the end of the age which he made reference to at the Olivet Discourse. One pastor who strongly subscribes to this perspective cites Jesus' words that these are the beginning of sorrows (beginning of labour pains);

If we use the metaphor of a pregnant woman, I believe that the Coronavirus marks the time when the water breaks, a visible sign that a person is now in labor. I use the explanation for the simple reason because, during pregnancy when the water breaks, it marks the very final stages of the pregnancy and generally anxiety begins and the event is notable and gets people to pay attention.

(Simelane 2020)

The pastor further claims that all along there has been agreement that the end times were approaching but there was no specific event people could point at, which marks the very end of the times. He adds that there had been epidemics in the past such as the SARS or the EBOLA, but they did not receive this worldwide attention as COVID-19 has done; hence "I believe COVID-19 is that event, especially since it happens throughout the world, almost all the nations of the world are affected, and are in some form of lockdown (Simelane 2020).

Backing up these sentiments on prophecies there is the perspective that God is using COVID-19 to revive people in readiness for Christ's coming, a revival that was also prophesied. God uses it to judge the gods that are being worshipped at this time. Whether the virus was created or not, it makes no difference. People were so used to worshipping sports, money, lust and perversion. Those evil habits have now been judged. People are not attending sports, businesses are crashing, gatherings and parties have been stopped. The Kingdom of Darkness has therefore been trounced as these gods belong to Satan, and through the confusion of the Coronavirus God passed judgment on the gods. Also, God has used this pandemic to create a space for the revival, such that people who didn't care about God before are now singing a different tune, as Christ's return is approaching.

\section{Church's response to COVID-19 government regulations}

From the analysis of the current situation, concerns rise on how the Christian community respond to the COVID-19 regulations and restrictions by government to help flatten the curve. There are Christians who preach against the spirit of fear and anxiety and that people should trust in God and believe his word than that of men. This is in contrary to the message from government and health authorities on precautionary measures that include being in isolation/ quarantine, practicing social distancing, wearing protective clothing at all times in public places and practicing hygiene 
through the use of alcohol-based hand sanitisers. It can be seen that the spread of the message from the church is actually a risk to the transmission of the virus since it leads many to be reluctant in obeying lockdown regulations. Many believe that prayer is key to fight demonic forces, and that they should now cleanse themselves in anticipation for the Second Coming of Jesus. Their perception that the pandemic is a spiritual warfare has therefore caused some people to be reluctant in the physical realm with regard to protecting themselves against the pandemic.

Some prominent church leaders in the country have ridiculed Christians that abide by the government regulations on precautionary measures against COVID-19, stating that they are weak in the faith and are carnal believers. In an open letter in one of the local newspapers titled "Church in bed with the enemy" the writer accuses the church that they have failed God by not resisting the regulations that prohibit churches from operating during the lockdown. He queries why churches are not being allowed to operate yet they are essential service providers. He notes that other businesses are being allowed to operate during the lockdown, which included bottle stores at the time of publication of the article (Sigwane 2020). The letter openly states that the work of God is being sabotaged and it forcefully states that Christians should be allowed to assemble without fear or favour.

Another article on the local newspaper shows one of the prominent pastors in the country blasting the government and legislators for their persistence that churches should only have 20 members attending in intervals. He blamed the government for the COVID-19 regulations that have still not put the churches on the list of essential service providers. He candidly labelled government's stance about the churches as 'national suicide' since people are being deprived of what they needed most during the times of COVID-19. According to him, this is a move that is betraying the duty of spiritual care that the people need. The pastor's argument was that churches are essential in providing emotional and social support, spiritual empowerment and it is where the sick would be healed from COVID-19. These churches could also be used for testing, educating and sensitising people about the virus.

Encouraging to Christians as it may sound, evidence from outside Eswatini gives us a different picture to this image. For instance, in Germany, after lockdown was eased, there were 40 new COVID-19 cases that were linked to a church service that was held in Frankfurt on the 10th of May 2020 , even though a social distance of $1.5 \mathrm{~m}$ was adhered to and there was a provision of hand sanitisers to the congregants (BBC 2020). In California, nine new cases of COVID-19 were linked to two mothers' day church services that were hosted in that state (Wigglesworth 2020). In neighbouring South Africa, just as the pandemic started around March 2020, a Church in Bloemfontein held a conference with some international guests that apparently were infected. There were about 300 people in attendance after which the Free State recorded 18 positive infections, with the bulk being from the church (Shange 2020). These are some of the many examples that provoke 
thoughts on whether the calls for churches to operate could really bind the nation of Eswatini together to fight this spiritual warfare or it could create elements of ignorance, detrimental to many lives.

Legislators in particular have reacted strongly against relaxing the number of people to attend church, wandering whether pastors of these churches are really concerned about the well-being of their congregations or they had other ulterior motives using the gospel. Evidence to this assertion is grounded on the fact that some of these churches have continued to hold services with 20 members in each service whereas hundreds are seen loitering around the church premises waiting for their turns to get inside. In so doing, the risk of the transmission is heightened, as sources claim that most of these members do not practice social distancing (Mkhonta 2020). However, the government authorities have not been silent but extended the arm of the law towards some of the church leaders that choose to break the lockdown regulations. Four pastors in the country have so far been arrested for defying these regulations. Some church leaders though, have responded positively to the government's directives and they remain at their respective homes and pray with their families. There are also those that access church sermons through online platforms on social media.

The introduction of the live stream services has been referred to by some in the religious community as an opportunity for Christians to practice self-discipline and love in practical ways through adhering to self-isolation. This to the church demonstrates self-value and honour to others. Since God gave to Christians a spirit of power, love, sound judgement and personal discipline, "following the lockdown regulations as a Christian is not an expression of unbelief but rather a definition and expression of wisdom and neighbourly love", claims one cleric (Times of Eswatini May 18, 2020).

\section{COVID-19 as experienced within traditional understanding}

Eswatini has a rich history on the interaction between traditional religious thought and Christian thought, since 1844 when Western missionaries first arrived in the country by royal invitation. This encounter marked an interface between two worldviews. B. J. Van der Walt (1994: 337) defines a worldview as "a mental construct that empowers action and endows rhythm and meaning to life processes. It is the foundation of customs, social norms, and law." As "an integrated, interpretative set of confessional perspectives on reality, [it] underlies, shapes, motivates and gives direction and meaning to human activity," adds Kosomo (2009: 35). African theologians have generally argued that the traditional worldview is irreplaceable, despite having interacted with other worldviews. Turner (1977) uses the term primal to explain religious systems that are traditional, saying that they are

the most basic or fundamental religious forms in the overall religious history of (hu)mankind and that they have preceded and contributed 
to the other great religious systems ... thus, they are both primary and prior; they represent a common religious heritage of humanity.

Oduyoye gives credit to the African primal worldview which she says comprises religious beliefs and practices that it has provided and continues to provide Africa with a philosophical fountainhead for the individual's life and for the ordering of society" (1979: 112). The thesis that this chapter therefore advances is that the response of the church in Eswatini to COVID-19 is largely shaped by the coexistence of two religious orientations that conform to one another; that is the traditional religious thought and the Christian thought. African theologians like Mbiti (1995); Bediako (1979); Turaki (1977); and Dickson (1984), amongst others explain the relationship between the two traditions as continuity. According to Walls (2002) it is continuity in the sense that the material of the Christian tradition is applied to already existing maps of universe shaped by the traditional worldview. Thus, the Christian impact on the pre-existing categories is not completely changed but reordered. However, Turaki is quick to give this caution concerning the parallels, that "to speak of continuity is not to imply a full convergence of ideas, for there is also a discontinuity between the two traditions; thus, this dialectic relationship must be recognized, and wrong conclusions must not be drawn".

Recurring in the responses of Christians to COVID-19, as presented earlier were that the epidemic is a punishment from God because of evil or sins that Emaswati are committing; it is a spiritual battle between two kingdoms, one headed by God and the other by Satan; and that it is a fulfilment of the end time prophecies. The following discussion seeks to explain why Emaswati have this perspective of COVID-19.

\section{As a punishment for sin}

Kosomo (2009) comes out with different classifications of evil, and one of them is moral evil. Accordingly, moral evil which he also calls sin is an act or an action performed by a free human person. Sin to Kosomo is an act of the will because it is a decision and indeed a free decision. Crenshaw (1983) adds another category of evil, namely, religious evil. According to him, religious evil signifies an inner disposition that perverts authentic response to the holy God. This perversion may assume the form of idolatry, where worship is directed away from God to a pale reflection of the ultimate. This type of evil operates on the vertical plane; it concerns human relationship with God and thus extends to the innermost recesses of imagination (Crenshaw 1983: 3). Notably, religious evil (sin) is more hidden than moral evil (sin), given that it operates on the vertical plane. It is therefore more pernicious since its presence can easily be concealed from human eyes (Kosomo 2009). 
The notions of sin or evil are existent in African religious consciousness. Magesa (1997) asserts that what in Christianity, is conceptualised and explained as "sin" or "evil", is better expressed in African religion by the concept of "wrong-doing", "badness", or "destruction of life." According to African traditional thought patterns, sin is always associated with humans; it cannot exist in the human experience except as perceived in people. Emphasising this point Kosomo (2009) states that it is people who are evil or sinful, whether or not they are aided by invisible forces.

However, according to Sawyer (1964) in traditional thought patterns sin is seen within the context of community life (as opposed to individualism), and any breach which punctures this communal relationship amounts to $\sin$. This makes the corporate solidarity of the family, the clan or the nation a fundamental factor of life. Relating this observation to the thesis of this chapter, we noted earlier that amongst the responses of the church in an Eswatini to COVID-19 was the call to national prayer and fasting, at the King's directive. The theme of the service (God heal our land), and the trending Bible verses suggested that Emaswati as a nation, collectively, have sinned before God. The pandemic comes as a punishment from God over the nation, hence the call to repentance as a community. Underlying this response from the church is the fact that Emaswati Christians experience the faith within the context of their traditional understandings. As noted by Nyawo (2017) when two religious orientations interact, the new orientation is only able to enlarge the traditional one; thus, a Swati Christian remains undeniably Swati in his or her perception of space (p. 372).

\section{As a spiritual battle between two kingdoms}

In Christianity there is a dualistic understanding which sees evil to be originating from or associated with spiritual beings other than God. Here, evil is personified, and the argument is that there is an evil divinity which God created good, but later turned against him and began to do evil. This evil divinity is assisted by evil spirits known as demons and all evil now comes from that lot. Thus, a kind of duel exists, between good and evil forces in the world (Kosomo 2009), and calamities like death, epidemics, locusts and other major catastrophes are caused by these evil forces. However, the power of Jesus released through prayer confronts the hollow powers of demons and spirits, and those of sickness, poverty and death (Hock 1995). It is for this reason that some Emaswati Christians view COVID-19 with spiritual lenses that it is a manifestation of the struggle between God and Satan. With regard to the traditional religious frameworks, the belief in mystical powers is dominant, and that they influence the course of human life. Mbiti calls these frameworks a worldview with a spirit world that is very densely populated with spirit beings (1969: 75). Designated as positive and negative, good and evil, the powers are said to bring blessings and curses. For safety and protection against the wrath of the evil powers people need a spiritual guidance 
and practical efforts for control, protection and security. The understanding and response of some Christians to COVID-19 therefore show that these categories of evil are interpreted within the frameworks of their traditional religious worldview; hence Hock's claim that at the bottom of traditional African concepts of demonic powers are specifically African concepts of evil (1995: 62).

\section{As a fulfilment of end time prophecies}

As noted earlier, another recurring theme in the Church's response to COVID-19 has been that there is nothing sinister about the virus, but rather, it is a sign of the Second Coming of Jesus Christ. For Christians the centre of their hope is Christ and His glorious appearing or Second Coming. They are waiting in anticipation of this future hope because, amongst other benefits, it will ultimately bring to an end the life of hardships on earth. Also, it will reunite community of Christians who died in Christ with those who will be living when Jesus returns. Thus, the reunion with loved ones and promised crowns by Jesus for demonstrating an upright life on earth, provide Christian an element of hope. Understanding COVID-19 as a fulfilment of prophecies about the end of times is popular amongst Christians and it is taken positively. This understanding resonates with the traditional tenets about life after death, which still confirms that some Emaswati Christians experience COVID-19 within the context of their traditional understanding. Life after death is a core belief in the traditional frameworks. It is believed that when a person dies, he transcends into another realm which is not as physical as earth, and he or she is conferred with supernatural powers; hence death is not the end but the beginning or in some cases continuation of life. This explains why death in most African traditions is not viewed as a tragedy; rather it is celebrated with several rites of passage (Hick 1976).

\section{Conclusion}

"The silent streets, shuttered stores, empty places of worship and of worry" birthed by COVID-19, as expressed by U.N. Secretary-General Antonio Guterres in the opening quotation of this chapter, have provoked different reactions in societies. This chapter has shown that Emaswati perceive the phenomenon as a God's punishment, a spiritual warfare and a fulfilment of prophecies. This kind of thinking is informed by their primal religious orientation which views the nation as a community, the universe as populated by both malevolent and benevolent spirits and life after death as a futuristic hope. However, whilst the people's understandings and responses to COVID-19 have the potential to bind the nation together and enable them to cope with the pandemic, it may also lead to fatalistic risks as infections and death rate continue to escalate. 
As noted above Emaswati Christians experience COVID-19 within their traditional frameworks, which are irreplaceable despite having interacted with other worldviews. Thus, it is imperative to balance their religious thought patterns as a coping mechanism, with practical approaches to the pandemic. The discussion has shown negative attitudes of some church leaders towards the COVID-19 compliance programme initiated by Eswatini Government. Barmania \& Reiss (2020) use the word 'gatekeepers' to describe the role played by religious leaders at their communities. This is to say they play a vital role in setting an appropriate tone for the church's response to life stressors and uncertainties. Church leaders are well-respected and trusted by the people in their own communities. When they talk to their church members, they listen because they (church members) believe in them, and their communities become anchors of social solidarity. So, if they demonstrate that they are taking seriously the facts of the situation and they adhere to all COVID-19 precautions, their followers will emulate them. If they model those acts of love that keep people safe, which include wearing a mask when in a public place, social distancing, and staying at home when feeling ill, church members will follow suit. Thus, their response to COVID-19 will be 'flying with both wings'; one wing being religion as a coping resource, whilst the other represents the practical steps to deal with the pandemic.

\section{Notes}

1 The Council of Swaziland Churches ecumenical body has not yet changed its official name to reflect Eswatini.

2 The discussion captured in this section comes from content analysis gathered from secondary sources.

\section{References}

Barmania, S., \& Reiss, M.J. (2020). Health promotion perspectives on the COVID-19 pandemic: The importance of religion. Global Health Promotion. doi:10.1177/1757975920972992

BBC. (2020). Coronavirus: Over 40 Covid-19 cases traced to church service in Germany. Retrieved from https://www.bbc.com/news/world-europe-52786242, 07 June 2020.

Bediako, K. (1979). "Continuity and discontinuity between the old testament and African life and thought." In African Theology en Route: Papers from the Pan-African Conference of Third World Theologians, December 17-23, 1977, Accra, Ghana, Kofi Appiah-Kubi and Sergio Torres (eds.), 59-65. Maryknoll, NY: Orbis Books, 1979.

Golomski, C. \& Nyawo, S. (2017). Christians' cut: Popular religion and the global health campaign for medical male circumcision in Swaziland. Culture, Health \& Sexuality. doi:10.1080/13691058.2016.1267409.

COVID-19 Eswatini Dashboard pioneered by UNESWA for daily updates on the development of Coronavirus in Eswatini, Africa and the world. Retrieved 
from https://datastudio.google.com/reporting/b847a713-0793-40ce-8196-e37d1cc 9d720/page/2a0LB, 6 June 2020.

Crenshaw, J. (1983). Theodicy in the Old Testament. Philadelphia, PA: Fortress Press. del Castillo, F.A., \& Alino, M. (2020). Religious coping of selected Filipino Catholic youth. Religions, 11, 462 .

del Castillo, F.A., del Castillo, C.D., \& Clyde Corpuz, J. (2020). Dungaw: Reimagined Religious Expression in Response to the COVID-19 Pandemic. April 2021. https://link.springer.com/article/10.1007/s10943-021-01266-x, 28 May 2021.

Dickson, K.A. (1984). Theology in Africa. Maryknoll: Orbis Books.

Dlamini, I. (2020). The coronavirus, a biblical perspective. Eswatini News. March 28, 2020.

Guterres, G. (2020). https://globalnews.ca/news/6807879/coronavirus-religious-leadersunited-nations/, 13 April 2020.

Hart, C.W., \& Koenig, H.G. (2020). Religion and health during the COVID-19 pandemic. Journal of Religion \& Health, 59, 1141-1143. doi:10.1007/s10943-020-01042-3.

Hick, J. (1983). Death and Eternal Life. London: MacMillan.

Hock, K. (1995). "Jesus Power-Super-Power" On the Interface between Christian. Fundamentalism and New Religious Movements in Africa. Mission Studies, 12(1), 56-70.

Holy Bible. New International Bible Version.

Hood, R., Hill, P., \& Spilka, B. (2009). Psychology of Religion (4th ed.). New York: Guilford Press.

International Religious Freedom Report: Swaziland. 2019. Washington: Bureau of Democracy, Human.

Koenig, H. (2012). Religion, Spirituality, and Health: The Research and Clinical Implications. ISRN Psychiatry, 2012 (278730), 1-34. doi:10.5402/2012/278730.

Kosomo, D. (2009). An investigation of sin and evil in African cosmology. International Journal of Sociology and Anthropology, 1(8), 145-155.

Magesa, L. (1997). African Religion: The Moral Traditions of Abundant Life. Nairobi: Pauline Press.

Mbiti, J.S. (1969). African Religions and Philosophy. London: Macmillan.

Mkhonta, S. (2020). Elijah Fire's Church Defiant. Eswatini Observer, Tuesday, April 14,2020, p. 2.

Nyawo, S. (2017). "Praying for Rain? African Perspectives on Religion and Climate Change." In The Ecumenical Review, Chitando, E. \& Conradie, E. (eds.). 69.3 A World Council of Churches Publication. Oxford: John Wiley \& Sons Ltd.

Oduyoye, Mercy Amba. (1979). "The Value of African Religious Beliefs and Practices for Christian Theology." In African Theology en Route: Papers from the Pan-African Conference of Third World Theologians, December 17-23, 1977, Accra, Ghana, Kofi Appiah-Kubi and Sergio Torres (eds.), 109-116. Maryknoll, NY: Orbis Books.

Sawyer. (1968). Sin and forgives in Africa. Frontier, 7, 60-63.

Shange, N. (2020). Covid-19: Bloemfontein Church that Hosted Infected Guests Says They Were Screened on Arrival in SA. Retrieved from https://www.timeslive. co.za/news/south-africa/2020-03-24-covid-19-bloemfontein-church-that-hostedinfected-guests-says-they-were-screened-on-arrival-in-sa/, 07 June 2020.

Sigwane, B.B.J. (2020). Church in Bed with the Enemy? Times of Eswatini, Wednesday, April 22, 2020. p. 27.

Simelane, B. (2020). PM Lobbies MPs for Support Times of Eswatini April 14, 2020. 


\section{Sonene Nyawo}

Times of Eswatini, May 18, 2020.

Turaki, Yusufu. (1999). Christianity and African Gods: A Method in Theology. Potchefstroom, South Africa: Potchefstroomse Universiteit vir CHO.

Turner, Harold W. (1977). "Primal Religions and Their Study." In Australian Essays in World Religions, Victor Hayes (ed.), 27-37. Bedford Park: Australian Association for World Religion.

United Nations Secretary-General Antonio Guterres Speech. Retrieved from https://globalnews.ca/news/6807879/coronavirus-religious-leaders-unitednations/. 13 April 2020.

Van der Walt, B.J. (1995). The Liberating Message: A Christian Worldview for Africa. Potchefstroom: IRS, 1994, Series F3, no. 44: 337.

Walls, A.F. (2002). The Cross-Cultural Process in Christian History. Edinburgh: T\&T Clark.

Wigglesworth, A. (2020). More COVID-19 Cases Linked to California Church Services. Retrieved from https://www.latimes.com/california/story/2020-05-24/ more-coronavirus-cases-linked-to-california-church-services, 07 June 2020. 